THURSDAY, MAY I9, I870

\section{SCIENTIFIC EDUCATION}

$T$ HAT the Government of this country is anxious to advance Science education is plainly manifest from what it has already done, in making large annual grants to institutions which it established, and which it maintains as its own. That it does not consider the present arrangements for this purpose as final or sufficient, is clear from the recent appointment of a Royal Commission to inquire into the whole question of Government aid to Science. The movement which resulted in the appointment of this Commission arose, as we have already explained, from a recommendation of the Council of the British Association for a formal inquiry into the existing state of Science education in this country; and the resolution stated: "That no such inquiry will be complete which does not include the action of the State in reation to scientific education, and the effects of that action upon independent educational institutions." Before the Commission meets, it seems desirable that those interested in advancing Science and Education generally, should seriously consider the different position in which Science now stands, as a means of education, to that which it formerly occupied. The time was, and not long ago, when Science was regarded as a thing by itself, having no connection with other branches of education, and useful mainly as a means for rendering men better machinists, better artisans, or discoverers of processes for the advancement of arts and manufactures. Many doubtless hold these opinions at present, and one concludes this to be the case from the very limited view which is expressed by the term "technical education" which is so generally used. Now, if it be desired to promote this view only, and to teach, Science alone, and not as a part of general education Government has established perhaps such schools as might meet the wants of the case, if it can be shown that they fulfil the expectations with which they were founded. But if the higher view, that Science is in its way as important a means of mental training as any other of the branches taught in our schools and universities, then some other method of extending Government assistance for its promotion must be adopted; and it is to this consideration we earnestly hope that inquiries will be directed. Since the first Report of the Science and Art Department, in 1854, sufficient time has been given to show whether the system then originated has answered its purpose. At page 2 of the Report, it is stated that its system will be "in the main selfsupporting; while the advantages will be distributed over every part of the United Kingdom; and the assistance received from Parliament be applied for the general good of all." It is generally believed that the system is not self-supporting, but that every associate of the School of Mines costs the Government a considerable sum of money. There can be no question that the advantages of the system are very great, directed as it is, in the several branches, by men of the highest possible eminence; but it is urged that they are not to any great extent distributed over the whole country, but mainly collected for the benefit of the technical schools founded by Government, and this tendency to force the official plan of education upon the country is regarded by many connected with other educational establishments as unfair. In fact, there is a threatened crusade against the Government professors.

To such we would remark, that the quantity of Science taught is so small, that it is not wise to attempt in any way to reduce that quantity; but it is certainly to be wished that the Commission should carefully inquire whether this method is one calculated to extend a sound Science education over the whole country, and whether it is possible to judge of a person's fitness to teach, without practical examination in subjects which are eminently practical, and without some guarantee that he has received a sound general education.

The Report further says: "It is essential that the institution should be supported to a considerable extent by the fees of pupils." This, it is urged, is not the case with the London Government school (and still less with the sister College of Science in Dublin), where the fees are not sufficient to pay the working expenses, to say nothing of the salaries of professors, and the scholarships of $£ 50$ per annum each, which are held by so large a number of students. At page 9 of the Report, the same important subject is dwelt upon: "My lords concur in the views expressed by the Lords of the Com= mittee of Trade, that every means should be used to render these institutions as much self-supporting as possible, and that, in the plans adopted, that object should always be borne in mind. My lords adopt this view, not only because they feel it incumbent upon them to confine the public expenditure to the lowest limit, but also because they entertain a belief that the utility of such institutions is great in proportion as they are self-supporting." It may not be generally known that large sums have been expended, and further large sums are to be expended, in building and fitting up laboratories, lecture-rooms, \&ce, at South Kensington. The present time, then, is a very fitting one for an inquiry as to the present wants and resources of the country in relation to the higher science teaching, and the means best calculated to utilize and develope them with due regard to efficiency and economy. If it can be shown that the School of Mines has really done more work than unendowed schools, in proportion to the sums spent upon it, let its sphere of action be enlarged-at South Kensington or elsewhere-and let its usefulness be increased. But it must always be remembered that it professes to give none other than a special training: that it in no way supplies the place of universities, colleges, and schools of general education. If, on inquiry, it is found that it has attained the object for which it was established, still that does not touch the recommendation of the Council of the British Association, which includes "the action of the State in relation to scientific education, and the effects of that action upon independent educational institutions." It certainly ought to be a subject of serious inquiry, whether or not such colleges as University College, London, which has for forty years trained and sent out into the world some of the most distinguished teachers of Science, which in fact originated the present system of scientific education in union with other branches of education ; or King's College, which has in like manner contributed so 
largely to advance modern education; or Owens College, Manchester, whose students show so well the nature of the education they there receive by the honours and prizes they gain at the London University; or many other flourishing colleges-should have their hands strengthened by Government help. In these institutions a thoroughly sound education, in all branches, is given. They have hitherto depended entirely on voluntary support, but the time has come when larger aid is needed to meet the modern requirements. Scholarships given by Government as incentives to work, and as helps to the many industrious students whose means are limited; stipends to professors, in order that they may obtain teaching assistance of a high character, of which they stand sorely in need, for it is absolutely impossible for them to teach effectively the large classes who place themselves under their guidance; grants for apparatus, and enlarged accommodation for the extension of original research-these are subjects which must occupy the attention of any committee appointed to inquire into the existing state of education. It is now pretty generally admitted by scientific men that no exclusively scientific education can meet our present requirements. On the Continent it is felt that it is only in universities and schools where all branches of knowledge are taught, that a really scientific education can be given; and we are glad to find that this opinion has gained ground in this country, together with a conviction that Science studies in their turn render students more apt in the acquisition of other branches of knowledge.

In Germany there is a strong feeling against the establishment of mere technical schools. It is maintained that boys should receive the same training up to a certain stage, and that they should afterwards enter for the special branch they design tofollow. Professor Köchly, of Heidelberg, Professor of Greek, proposes that there should be a thorough but limited instruction in classics, a more extended development of mathematics, a course of instruction in the natural sciences, and systematic instruction in modern languages. Professor Hofmann, who is well known in this country, considers that the best safeguard against the vulgarising of Science, when it is taught with too special a regard to its applications, is to be found in a sound general school training; and he believes that the old gymnasium system is of inestimable value. He asserts that in scores of instances he has seen youths who have come to the chemistry classes in the University of Berlin, with scarcely a knowledge of the meaning of the word chemistry, but who have been well trained in a gymnasium, in a short time completely surpass their fellows, who, in a school of another kind, have acquired considerable knowledge of the elements of chemistry. All the Polytechnic Schools of Germany are rapidly approaching the university type; - the teaching of the principles of Science, and not of the applications, is becoming more and more the main object.

\section{LEONARDO DA VINCI AS A BOTANIST}

$\mathrm{F} E W$ men have better earned the title of universal genius than Da Vinci. An ardent disciple of Nature, disdaining mere superficial knowledge, he went to the root of whatever he took up, and attained an intimate acquaintance especially with everything that bore on his beloved art of painting. And this art was understood by him in its widest sense. Not content with representing the mere outward appearance of Nature or of the human form, he considered it a part of his business as a painter to investigate the laws which produce those appearances or which govern that form in its healthy state. To the long list of his acquirements given in the catalogue of the Louvre collection, as painter, sculptor, architect, engineer, physicist, writer, and musician, may now be added that of botanist. In the first number of a new botanical journal, Nuovo Giornale Botanico Italiano, published at Florence, Sig. G. Uzielli has given some interesting extracts from a work by $\mathrm{Da}$ Vinci, from which he would appear to have anticipated the discovery of certain botanical laws generally attributed to writers of a later age. These extracts are taken from a section of his great treatise on painting, entitled "On Trees and Vegetation," which, however, is found only in one edition of that work, the Roman. The following are the points on which the originality of his observations deserves especial mention.

1. The laws of Phyllotaxis, or of the arrangement of leaves on the stem. Da Vinci appears to have been the first to observe that the order of growth of the leaves is uniform in the same species; and that their modes of arrangement can be divided into three principal forms -.the opposite, the whorled or verticillate, and that usually denominated in text-books the alternate, but which should rather be called the spiral. He also pointed out that in the case of leaves growing in opposite pairs, they are generally arranged in a "decussate" manner, that is, each pair grows at right angles to the pairs immediately above and below it; that when leaves are verticillate, those in each whorl are seldom in a direct line with those in the whorls immediately above and beneath ; and that a very common form of the spiral arrangement is that sometimes called "quincuncial," where the cycle is completed by five leaves, the sixth being in a direct line with the sixth above and beneath. Another observation of the great painter's is, that inasmuch as branches grow from buds generated in the axils of leaves, the arrangement of the branches on the trunk necessarily corresponds to that of the leaves on the stem.

In botanical works it is generally stated that Sir Thomas Browne, in his quaint little treatise "The Garden of Cyrus, or the Quincuncial Lozenge," published in 1658 (a work not mentioned in Pritzel's "Thesaurus Litteraturæ Botanicæ"), was the first to describe the spiral disposition of leaves, which was afterwards noticed contemporaneously by Grew and Malpighi. Bonnet,* however, in x754 followed out the laws of phyllotaxis in a far more exact manner; and the subject has been still further elucidated by Goethe, Schimper, Braun, Steinheil, the brothers L. and E. Bravais, and Martins. To Da Vinci, however, who lived from 1452 to 1519 , is clearly due the priority in the discovery of these laws; although, as might be expected, many of his observations show a crudeness and imperfection which have been corrected by more recent writers.

2. The manner in which, from the structure of the trunk of exogenous trees, their age can be determined. This fact, although now familiar to unscientific persons, appears to have been unknown to the ancients; since Theophrastus makes no mention of it, nor does Pliny, who

* Bonnet, $\mathrm{Ch}$., Recherches sur l'usage des feuilles dans les plantes. 